\title{
Insights into the Mechanisms of Gastric Adaptation to Aspirin-Induced Injury: A Role for Regenerating Protein but Not Trefoil Peptides
}

\author{
Barbara M. Alderman, Meera Ulaganathan, Louise M. Judd, Meegan Howlett, \\ Lorraine M. Parker, Neville D. Yeomans, and Andrew S. Giraud \\ University of Melbourne, Department of Medicine, Western Hospital, Footscray, Victoria, Australia
}

\begin{abstract}
SUMMARY: The phenomenon of reduced gastric mucosal injury despite repeated doses of a damaging agent is termed adaptation. Adaptation to nonsteroidal anti-inflammatory drug-induced injury has been clearly demonstrated in both humans and experimental animals; however, the precise mechanisms remain unclear. We hypothesized that mediators of adaptation might be the regenerating protein (Regl) and the trefoil peptides TFF1 and TFF2, because these proteins play pivotal roles in gastric mucosal protection and repair. The gene expression and the protein levels of these proteins were measured and compared in normal, aspirin-injured, and aspirin-adapted rat stomachs. TFF gene and protein expression levels were similar in all three groups, whereas Regl gene expression and protein levels in adapted stomach were increased. A time course analysis of Regl expression during the onset and offset of adaptation showed that mucosal Regl increased during the development of adaptation, was maintained during subsequent aspirin dosing, and returned to baseline levels once dosing had ceased and adaptation was lost-indicative of a causal role in the adaptation process. Colocalization of increased Regl with gastric epithelial areas showing increased proliferation also suggests that Regl may be an important mediator of the resolution of mucosal injury that is characteristic of gastric adaptation to aspirin. (Lab Invest 2003, 83:1415-1425).
\end{abstract}

$A$ reduction in aspirin-induced gastric mucosal injury during repeated dosing with this damaging nonsteroidal anti-inflammatory drug (NSAID) was first observed in dogs approximately 40 years ago (Hurley and Crandall, 1964). This phenomenon was later termed "adaptation" (St John et al, 1973) and has since been observed after the repeated administration of a number of different NSAIDs in both humans (Graham et al, 1983; Lipscomb et al, 1995; Shorrock et al, 1990) and experimental animals (Skeljo et al, 1992, 1996). Despite being observed and quantified for many decades, the precise mechanisms and mediators of adaptation remain unclear, but some contributory factors are beginning to be uncovered.

Adaptation is a prostaglandin-independent phenomenon (Konturek et al, 1994b; Shorrock and Rees, 1992; Wallace et al, 1995), is both time and dose dependent (Graham et al, 1988; Lipscomb et al, 1995; Shorrock et al, 1990; Skeljo et al, 1992, 1996; Wallace et al, 1995), and confers protection mostly against deep (that is, injury that extends below the pits into the gastric glands) rather than superficial gastric epithelial injury (Graham et al, 1983; Skeljo et al, 1992, 1996).

DOI: 10.1097/01.LAB.0000092231.54761.CD

Received June 12, 2003.

This work was supported by a grant from the National Health and Medical Research Council of Australia.

Address reprint requests to: Assoc. Prof. Andrew S. Giraud, University of Melbourne, Department of Medicine, Western Hospital, Footscray, Victoria, Australia, 3011.E-mail: asgirand@unimelb.edu.au
We have shown that NSAID-induced apoptosis is suppressed in adapted stomach (Alderman et al, 2000). Adaptation is strongly associated with increased gastric epithelial cell proliferation (Baumgartner et al, 1986; Eastwood and Quimby, 1982; Konturek et al, 1994b; Lev et al, 1972; Levi et al, 1992; Shorrock et al, 1990; Yeomans et al, 1973) and increased mucosal expression of transforming growth factor-alpha (TGF- $\alpha$ ) (Doljanin et al, 1996; Konturek et al, 1998b; Romano et al, 1996; Stachura et al, 1996).

A number of different growth factors and hormones are known to influence gastric epithelial proliferation (Jones et al, 1999)_one that has recently been implicated in the process of cellular proliferation in the gut, and may be a candidate mediator of adaptation, is regenerating protein (Regl).

Regl was first isolated in 1988 (Terazono et al, 1988) and, although much of the research to date has been concentrated on its role in the pancreas, it has also been shown to be expressed in normal stomach (Watanabe et al, 1990) and to increase after acute gastric mucosal injury (Asahara et al, 1996; Kawanami et al, 1997). In keeping with its mitogenic role in regenerating pancreatic islets, it has been suggested that Regl facilitates normal proliferation in the gastric epithelium and may also augment the proliferation of gastric epithelial cells after injury.

Other candidate mediators of adaptation are members of the trefoil peptide family (TFF). These are small polypeptides that are synthesized by mucous cells of the gut. There are three known mammalian trefoils: TFF1 and TFF2, which are expressed mainly in the 
stomach (Hanby et al, 1993; Jeffrey et al, 1994; Rio et al, 1988; Taupin et al, 1995; Tomasetto et al, 1990); and TFF3, which is expressed mainly in the intestine and colon (Podolsky et al, 1993; Suemori et al, 1991; Taupin et al, 1995).

Studies aimed at investigating their function in the gut have shown that the trefoils enhance epithelial defense mechanisms by interacting with, and likely stabilizing mucins (Kindon et al, 1995; Rio et al, 1988; Tomasetto et al, 2000); stimulate migration of epithelial cells, thereby aiding the restitutive phase of epithelial repair (Chinery and Playford, 1995; Dignass et al, 1994; Playford et al, 1995); and possibly play roles in cellular differentiation and glandular renewal (Cook et al, 1997; Familari et al, 1998; Taupin et al, 2001). These properties suggest that the trefoil peptides might also be candidates for mediating adaptation.

We describe the results of experiments measuring the gene and protein expression levels of Regl and its receptor (Regr) and the trefoil peptides, TFF1 and TFF2, in normal, aspirin-injured, and aspirin-adapted rat stomachs to determine whether these proteins might play roles in the mechanism of gastric mucosal adaptation to injury.

\section{Results}

\section{Quantification of Adaptation}

The method for quantification of mucosal damage in the three groups of rats from which the tissue samples were taken has been reported elsewhere (Alderman et al, 2000). Briefly, each group of rats was dosed daily for 6 days: the control group received vehicle alone; the single dose (or aspirin-damaged) group received vehicle for 5 days followed by a single dose of aspirin (120 mg/kg) on the sixth day; and the adapted group received aspirin $(120 \mathrm{mg} / \mathrm{kg})$ each day. All rats were killed 4 hours after the last dose on the sixth day, and macroscopic injury was assessed by a blinded observer.

Damage in the control group was barely detectable, being $0.04 \pm 0.03 \mathrm{~mm}^{2} / \mathrm{cm}^{2}$ (mean \pm SEM) of the mucosal surface. The mean area of macroscopically visible hemorrhagic damage in normal stomach after a single dose of aspirin was $1.3 \pm 0.3 \mathrm{~mm}^{2} / \mathrm{cm}^{2}$, and this was reduced to $0.35 \pm 0.17 \mathrm{~mm}^{2} / \mathrm{cm}^{2}(p<0.05)$ after the last dose of aspirin in the adapted animals. In seven of the nine rats in the adapted group, there was virtually no macroscopically visible damage. Figure 1 shows typical nonadapted (Fig. 1A) and adapted (Fig. 1B) rat stomachs 4 hours after a $120 \mathrm{mg} / \mathrm{kg}$ dose of aspirin.

\section{Quantification of TFF mRNA and Protein Expression}

RT-PCR analysis of the expression of trefoil peptide mRNA in undamaged (vehicle-treated), single dose, and adapted rat stomachs is shown in Figure $2 \mathrm{~A}$. No significant differences in the abundance of TFF1 or TFF2 mRNA in the gastric mucosa of rats that had adapted to aspirin $[1.35 \pm 0.06$ (TFF1), $1.14 \pm 0.12$ optical density (OD) units (TFF2)] were detected com-
A

B

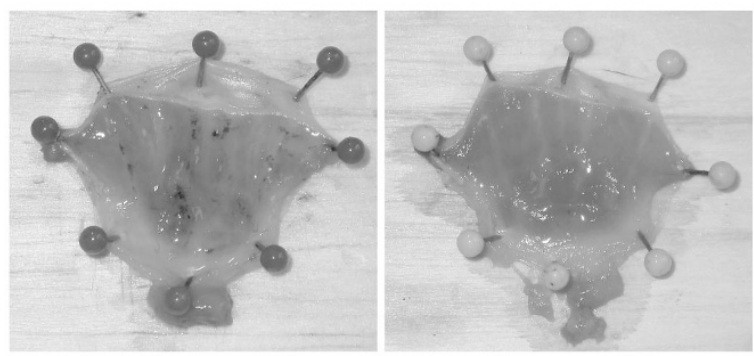

Figure 1.

The process of adaptation is characterized by a marked reduction of gastric mucosal injury after several doses of a damaging agent. Representative photographs of rat stomach 4 hours after a single dose of $120 \mathrm{mg} / \mathrm{kg}$ aspirin showing hemorrhagic erosions $(A)$ and adapted rat stomach 4 hours after 120 $\mathrm{mg} / \mathrm{kg}$ aspirin (B).

pared with either the control $(1.53 \pm 0.02,1.32 \pm 0.12$ OD units) or single-dose $(1.39 \pm 0.08,1.18 \pm 0.018$ OD units) animals.

Quantification of TFF1 and TFF2 protein levels in the three treatment groups by RIA (Fig. 2B) strongly correlated with the mRNA expression analysis, showing no significant changes in the gastric mucosal levels of the trefoil peptides among the control [137 \pm 9 (TFF1), $1.3 \pm 0.1$ (TFF2) fmol $/ \mu \mathrm{g}$ protein], single-dose (107 \pm $8,1.1 \pm 0.1 \mathrm{fmol} / \mu \mathrm{g}$ protein), and adapted (113 \pm 9 , $1.0 \pm 0.1 \mathrm{fmol} / \mu \mathrm{g}$ protein) animals.

\section{Visualization of TFF1 mRNA and Protein Expression}

In situ hybridization and immunohistochemistry techniques were used to visualize the patterns of gene and protein expression of the major stomach trefoil peptide TFF1. In normal stomach, TFF1 was highly and specifically expressed at the surface of the epithelium by surface mucous cells (Fig. 3, A and D). After a single damaging dose of aspirin, expression of TFF1 was lost specifically at focal sites of injury where there had been loss of surface mucous cells (Fig. 3, B and E). In adapted stomach after the last of multiple doses of aspirin (Fig. 3, C and F), TFF1 expression remained similar to that of nonadapted stomach, with some focal areas of lost expression at sites of surface mucous cell sloughing.

The areas of focal erosions where losses of TFF1 were observed, were small in comparison with the total fundic area of the stomach in both the adapted and single-dose groups-this was reflected in the quantification of TFF1 by RT-PCR and RIA by trends toward, rather than significant, decreases being detected.

\section{Regl/Regr mRNA and Regl Protein Expression}

RT-PCR analysis of Regl gene expression in normal, aspirin-damaged, and aspirin-adapted stomach (Fig. $4 \mathrm{~A})$ showed a 2- to 3-fold increase in the level of Regl mRNA in adapted stomach (1.45 \pm 0.11 OD units, $p<$ $0.001)$ compared with both normal $(0.54 \pm 0.04)$ and single-dose aspirin-damaged stomach $(0.77 \pm 0.10)$. 

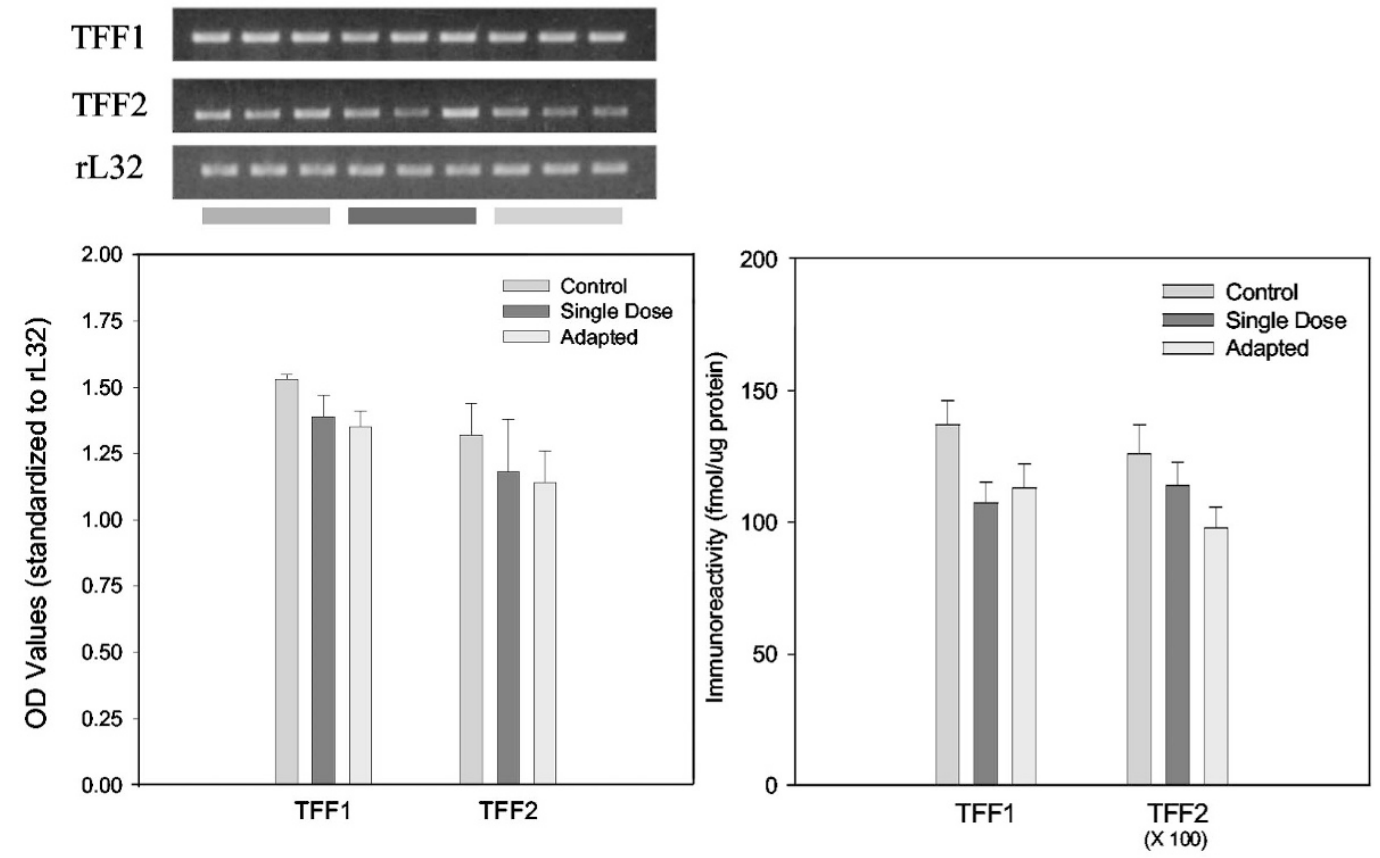

Figure 2.

A, Gene expression analysis of the trefoil peptides TFF1 and TFF2 in the gastric mucosa of control, single-dose, and adapted rats 4 hours after the last dose of vehicle (control) or aspirin (single-dose and adapted). Optical density (OD) values were standardized with ribosomal protein L32 (rL32) and are expressed as means \pm sEM ( $n=9$ per group). B, Quantification of trefoil peptide expression in control, single-dose, and adapted rat stomach by radioimmunoassay. The immunoreactivities of TFF1 (fmol $/ \mu \mathrm{g}$ protein) and TFF2 (fmol $\times 10^{-2} / \mu \mathrm{g}$ protein) are expressed as means \pm SEM ( $n=9$ per group).

For Regr, no changes in gene expression were detected among any of the three groups: control, $1.17 \pm$ 0.06 OD units; single dose, $1.11 \pm 0.05$; and adapted, $1.11 \pm 0.08$ (Fig. 4A).

Similarly, Western blot analysis showed a 2- to 3-fold higher expression of the Regl protein (17 kDa) in aspirin-adapted stomach (566 \pm 112 OD units, $p<$ $0.05)$ compared with both normal (235 \pm 27 OD units) and single-dose (276 \pm 60 OD units) stomach as shown in Figure 4B.

\section{Visualization of Regl mRNA and Protein Expression}

In situ hybridization and immunohistochemistry showed that, in normal stomach, Regl mRNA and protein were located mainly in the lower half of the gastric epithelium (Fig. 5, A and D). In normal stomach after aspirin, Regl expression was increased specifically at sites of obvious injury, with normal levels of Regl at the margins (Fig. 5, B and E). The expression of Regl in adapted mucosa was also high in close proximity to sites of injury, but it was also increased in areas that were relatively undamaged or recently healed (Fig. 5, C and F).

\section{Gastric Damage and Regl Gene Expression During the Onset and Offset of Adaptation}

To help determine whether the increase in Regl found in adapted stomach might be causal, Regl expression was measured during the onset and offset of adaptation to aspirin-induced injury. Macroscopic injury to the gastric mucosa was measured in rats given vehicle and/or $120 \mathrm{mg} / \mathrm{kg}$ aspirin daily for 9 days as detailed in Figure 6A.

As expected, the vehicle-only control group showed minimal amounts of macroscopically detectable injury (0.08 $\pm 0.07 \mathrm{~mm}^{2} / \mathrm{cm}^{2}$, Group 1), whereas a single dose of aspirin caused the highest degree of injury $\left(1.30 \pm 0.13 \mathrm{~mm}^{2} / \mathrm{cm}^{2}\right.$, Group 2). After three doses of aspirin, macroscopically detectable gastric injury was beginning to decrease as the adaptive process began $\left(0.80 \pm 0.19 \mathrm{~mm}^{2} / \mathrm{cm}^{2}\right.$, Group 3), with minimal injury occurring 4 hours after the last of six daily doses when adaptation was well established $\left(0.16 \pm 0.07 \mathrm{~mm}^{2} /\right.$ $\mathrm{cm}^{2}$, Group 4). For the offset group, after six daily doses of aspirin (when adaptation had fully developed), rats received two daily doses of vehicle and were then rechallenged with aspirin on the following day. The stomachs of these rats showed levels of mucosal damage approaching that of the single-dose group (1.01 $\pm 0.21 \mathrm{~mm}^{2} / \mathrm{cm}^{2}$, Group 5), indicative that adaptation to injury had been mostly lost. The last group of rats was treated in the same way as the adaptation offset group (Group 5) except that they received a final dose of vehicle instead of aspirin, and this group (Group 6) showed no macroscopically detectable injury. 
$\mathbf{A}$

D

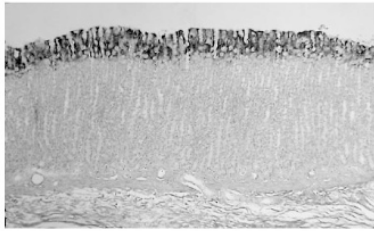

B

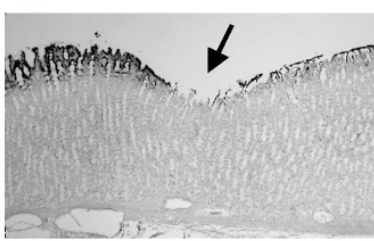

C

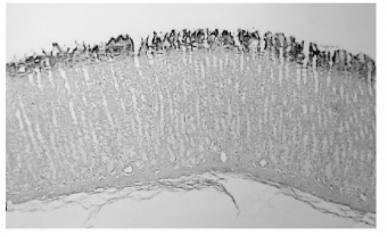

Figure 3.

In situ hybridization of TFF1 in normal (A), single-dose (B), and adapted (C) rat gastric epithelium. In normal and adapted epithelium, TFF1 mRNA was highly and specifically expressed by surface mucous cells ( $A$ and $C$ ). Four hours after a single dose of $120 \mathrm{mg} / \mathrm{kg}$ aspirin, unadapted rat stomach showed loss of TFF1 mRNA expression at focal sites of injury (B). Similarly, TFF1 immunohistochemistry showed expression of TFF1 protein specifically in surface mucous cells in normal and adapted epithelium ( $D$ and F), with some loss of expression at sites of injury after a single dose of aspirin $(E)$.

Gastric mucosal Regl gene expression was measured by RT-PCR in the control, onset, adapted, and offset groups of rats (Fig. 6B). Regl gene expression reached its peak in the group of animals that were beginning to develop adaptation after 3 days of aspirin dosing (3.51 $\pm 0.53 \mathrm{OD}$ units, Group 3) compared with both the single-dose aspirin group (1.60 $\pm 0.06 \mathrm{OD}$ units, Group 2) and the vehicle controls $(0.97 \pm 0.09$ OD units, Group 1). This maximal level of Regl expression was maintained while aspirin dosing continued and adaptation was fully established $(3.21 \pm 0.43 \mathrm{OD}$ units, Group 4). Three days after aspirin dosing had ceased, mucosal Regl expression returned to the baseline level (1.30 \pm 0.20 OD units, Group 6). Interestingly, previously adapted stomachs that were rechallenged with aspirin after several days offset showed an increased Regl response to injury (2.98 \pm 0.45 OD units, Group 5) compared with stomachs that had not been previously adapted (Group 2). Quantification of Regl mRNA expression by RT-PCR in the adaptation time course study was confirmed by Northern blotting (Fig. 6C).

\section{Colocalization of Enhanced Regl Expression with Increased Epithelial Cell Proliferation}

In situ hybridization for Regl and immunohistochemistry for proliferating cell nuclear antigen (PCNA) were performed on sections from normal, injured, and adapted rat stomachs to determine whether areas that showed enhanced expression of Regl colocalized with areas showing increased epithelial cell proliferation (Fig. 7).

After aspirin, increases in both Regl and PCNA were observed in proximity to sites of injury (black arrows, Fig. 7, A/C and B/D) compared with basal expression in adjacent, uninjured epithelium (gray arrows, Fig. 7, $\mathrm{A} / \mathrm{E}$ and $\mathrm{B} / \mathrm{F}$ ). In adapted stomach, stronger and more extensive expressions of both Regl and PCNA were clearly colocalized in healing, intact epithelium compared with normal epithelium (Fig. 7, G versus E, and $H$ versus $F$ ).

\section{Discussion}

Our results suggest that increased expression of Regl may contribute to the adaptation of the gastric epithelium to repeated aspirin-induced injury. Such a role is plausible in view of the known associations of Regl with injury and repair in the upper gut and its suggested role as a mitogen/growth factor.

It has been clearly demonstrated that Regl is expressed only in endocrine cells, mostly enterochromaffin-like (ECL) cells, in normal and injured rat stomach (Asahara et al, 1996). Four hours after exposure to aspirin in rats, we found the number of cells expressing Regl increases specifically in areas close to injury sites, in keeping with the findings of others (Asahara et al, 1996; Kawanami et al, 1997). Once adaptation is established, the number of Reglexpressing cells, and also the level of expression, is increased not only in areas that are injured but also throughout the mucosa in areas that appear macroscopically normal but are likely healing from earlier injury.

Studies on cultured rat gastric ECL cells have shown that the growth factor TGF- $\alpha$ increases ECL cell number by inhibiting cytokine-induced apoptosis (Mahr et al, 1998). Considering this, together with our finding that apoptosis is reduced (Alderman et al, 2000) and TGF- $\alpha$ is increased in adapted stomach (Doljanin et al, 1996; Romano et al, 1996), it is plausible that increased expression of TGF- $\alpha$ during adaptation might be an upstream signal that contributes to increased numbers of gastric mucosal ECL cells, in turn enhancing mucosal levels of Regl.

The gastric epithelium is not fully protected even after adaptation is established. We and others have shown that adaptation is protective mostly against deep mucosal injury that causes macroscopically visible hemorrhagic lesions (Graham et al, 1983; Skeljo et al, 1992, 1996). It is possible that the augmented mucosal expression of Regl in adaptation is maintained as a result of the superficial sloughing of surface mucous cells that occurs after each daily dose of aspirin-possibly via inflammatory mediators. Several studies have implicated inflammatory cytokines in the stimulation of Regl expression (Dusetti et al, 1995, 1996; Gurr et al, 2002). Moreover, inflammatory cell infiltrate (and myeloperoxidase activity) increases in the gastric mucosa after a single aspirin dose, and this activated inflammatory response continues during 

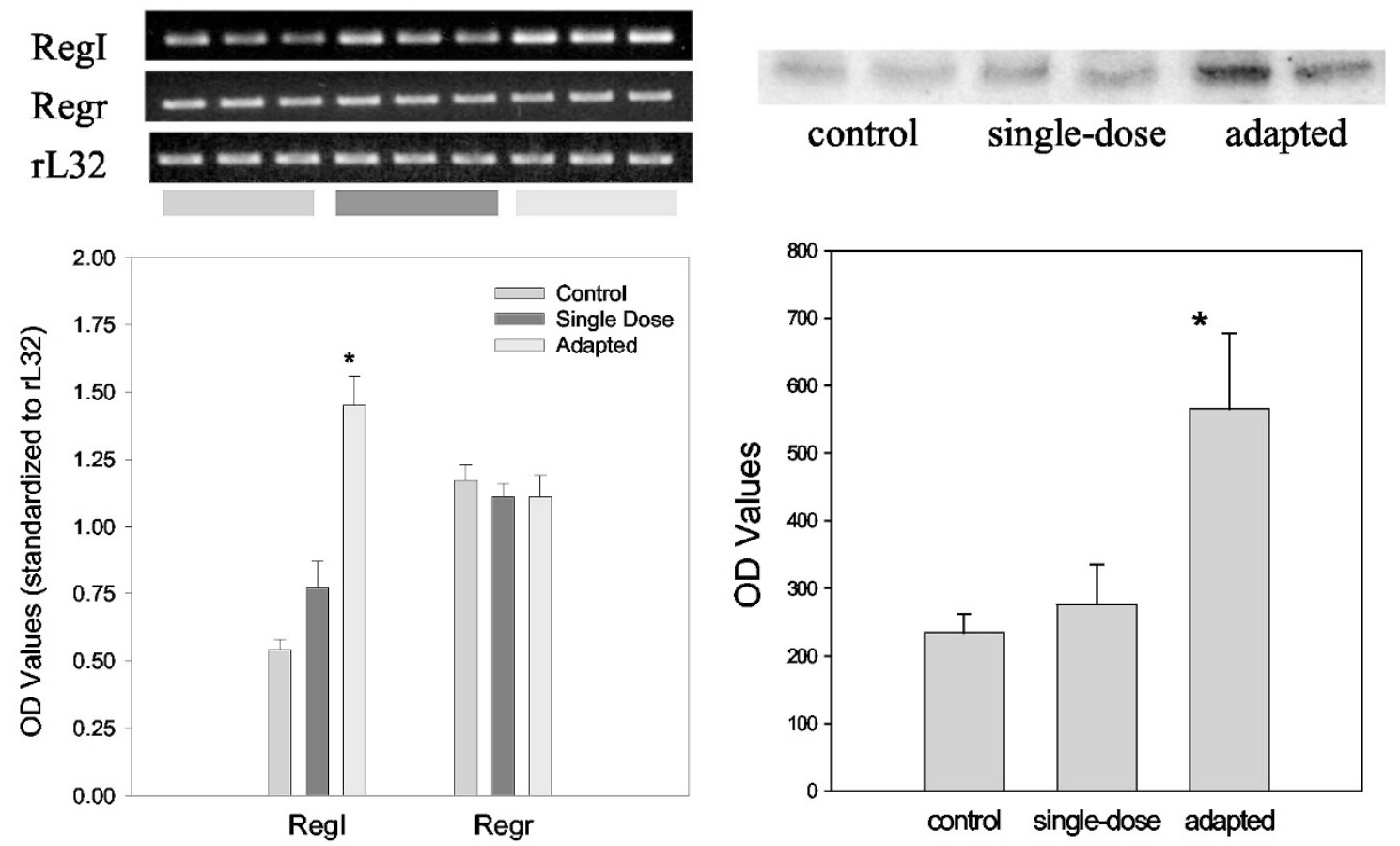

Figure 4.

A, mRNA expression of regenerating protein (Regl) and its receptor (Regr) in the gastric mucosa of control, single-dose, and adapted rats 4 hours after the last dose of vehicle or aspirin. Results are expressed as mean OD \pm SEM, standardized using rL32 values ( $n=9$ per group). ${ }^{*} p<0.05$ compared with both the control and single-dose groups. B, Western blot analysis of Regl protein in control, single-dose, and adapted rat stomach 4 hours after the last dose of vehicle or aspirin. Results are expressed as mean $\mathrm{OD} \pm \mathrm{SEM}\left(n=9\right.$ per group). ${ }^{\star} p<0.05$ compared with both the control and single-dose groups.

long-term use and the subsequent onset of adaptation in both humans and rats (Shorrock et al, 1990; Stachura et al, 1994; Wallace et al, 1995).

Regl expression has been shown to increase up to 10-fold after a single high dose of indomethacin or after acute water immersion restraint stress (Asahara et al, 1996; Kawanami et al, 1997). In contrast, Regl was not significantly increased in the mucosa after the first aspirin dose in our experiments, although focal increases in expression at sites of injury were observed. This is in keeping with the lesser degree of injury caused by the aspirin dose used in this study compared with the other more extensive injury models. Similarly, measurable increases in TGF- $\alpha$ and epidermal growth factor also occur in adapted stomachs only after multiple doses of aspirin and not after a single injurious dose (Doljanin et al, 1996; Konturek et al, 1994a, 1998a; Romano et al, 1996). It is possible that the increments in mucosal Regl (and indeed TGF- $\alpha$ and epidermal growth factor) that occur as a result of each adapting dose finally culminate as an "effective" increase only after several episodes of daily injury-this would help to explain the lag time of several days required for the onset of adaptation (Skeljo et al, 1996; St John et al, 1973; Wallace et al, 1995).

Whether increased Regl expression plays a causal role in adaptation by enhancing gastric epithelial re- pair processes cannot be answered with complete certainty until adaptation is attempted in Regl knockout animals. However our time course analysis on Regl expression during the onset and offset of adaptation is strongly indicative of a causal role, because Regl expression peaked as acute injury was reducing and the augmented expression of Regl was maintained during subsequent aspirin dosing and the full development of adaptation, returning to baseline level once aspirin dosing had ceased for several days. Moreover, previously adapted mucosa seems to be "primed" because Regl expression increases again very rapidly as soon as aspirin dosing is resumed after a brief interruption. Also indicative that Regl might play a causal role in the adaptation process are our results showing colocalization of increased Regl expression with enhanced epithelial cell proliferation.

One of the most consistent features of adaptation is a progressive increase in the proliferation of cells in adapting gastric epithelium. Several studies in both humans and experimental animals using histologic assessments and incorporation of ${ }^{3}[\mathrm{H}]$ thymidine and bromodeoxyuridine conclude that enhanced proliferation likely contributes to the mechanism of reduced injury that is characteristic of gastric mucosal adaptation (Baumgartner et al, 1986; Eastwood and Quimby, 1982; Konturek et al, 1994a; Lev et al, 1972; Levi et al, 1992; Romano et al, 1996; Shorrock et al, 1990). A role 
A

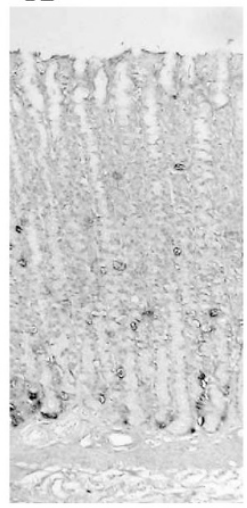

D

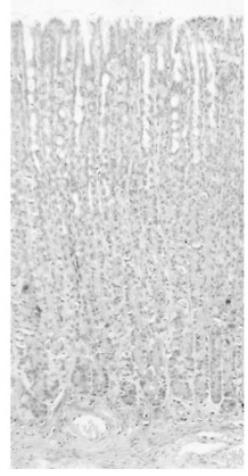

\section{Figure 5.}

In situ hybridization of Regl in rat gastric epithelium. In normal rat stomach, Regl mRNA is expressed in cells located mainly in the lower half of the epithelium (A). The number of cells in which Regl mRNA is detected is increased at sites of injury 4 hours after aspirin (B). In adapted stomachs, Regl mRNA expression is increased in areas that are essentially microscopically normal (C). Similarly, immunohistochemistry shows normal expression of Regl protein mainly in the lower half of the epithelium (D), with increased expression at sites of injury in unadapted stomach (E). In adapted stomach, Regl protein expression is also increased in undamaged and healing epithelium (F).

for Regl in cellular proliferation is well demonstrated in pancreas (Francis et al, 1992; Miyaura et al, 1991; Watanabe et al, 1994), and Regl has also been implicated as exerting trophic effects on the gastric epithelium (Asahara et al, 1996; Fukui et al, 1998; Higham et al, 1999; Kawanami et al, 1997; Kazumori et al, 2000). Moreover, our results show clear evidence of concordantly increased expression of Regl and PCNA in both damaged and healing gastric epithelium.

We report here that, unlike Regl, the gene expression level of the Reg receptor was not changed in adapted stomachs, in keeping with another report that Regl-associated regeneration and proliferation in the pancreas are primarily regulated by the expression of Regl protein and not by regulation of its receptor (Kobayashi et al, 2000).

Unlike Regl, we found no evidence for a likely role of trefoil peptides in mediating adaptation. Trefoil peptide synthesis in the gastric mucosa is induced after acute and extensive ulceration caused by exposure to cryoprobes, acetic acid, or large doses of NSAIDs (Alison et al, 1995; Ulaganathan et al, 2001) and also
A
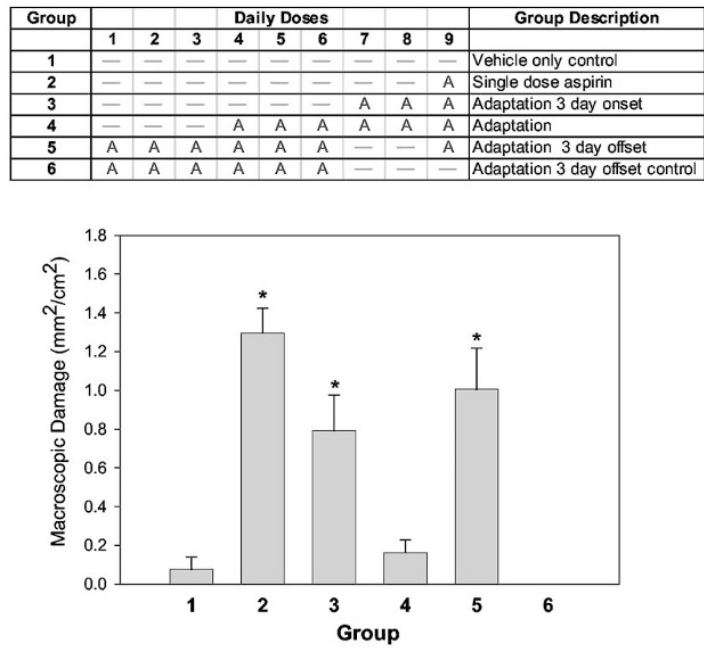

B

RegI

rL32
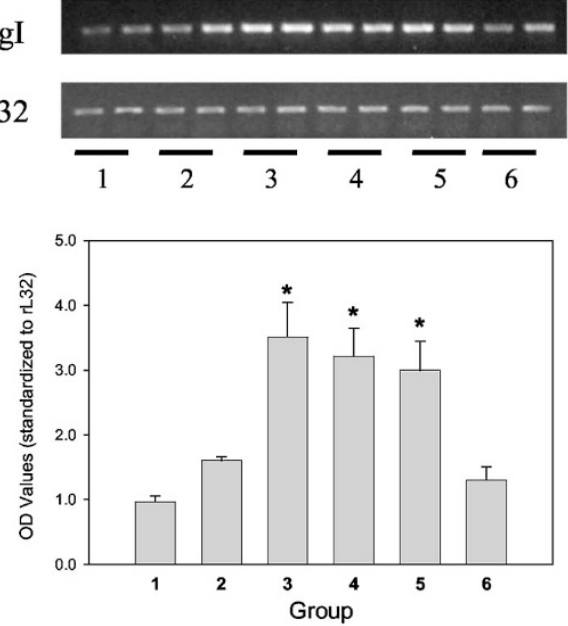

C

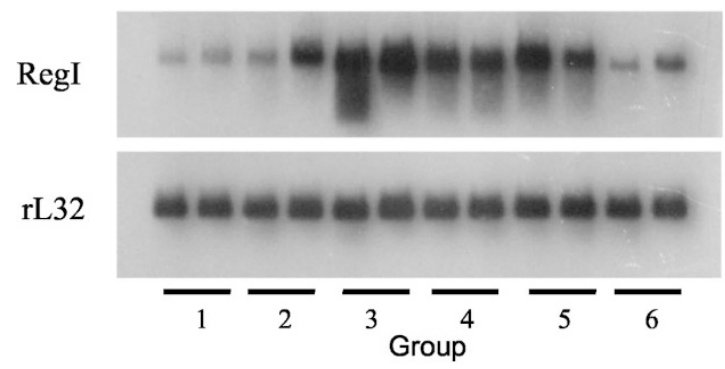

Figure 6.

Onset and offset of adaptation to aspirin. A, Macroscopic gastric epithelial injury after varying daily doses of vehicle or $120 \mathrm{mg} / \mathrm{kg}$ aspirin as outlined $(n$ $=5-6$ per group). ${ }^{*} p<0.05$ compared with the control, adapted, and offset control groups $(1,4$, and 6 , respectively). Regl during onset and offset of adaptation to aspirin. B, RT-PCR of Regl mRNA in the corresponding treatment groups (as outlined in A) ( $n=5-6$ per group). ${ }^{*} p<0.05$ compared with the control, single-dose, and offset control groups (1,2, and 6 , respectively). C, Northern blot of Regl and rL32 showing $n=2$ from the corresponding treatment groups (as above)

after acute severe injury induced by water immersion and restraint stress and indomethacin (Konturek et al, 1997; Playford et al, 1995). Our results show that the 

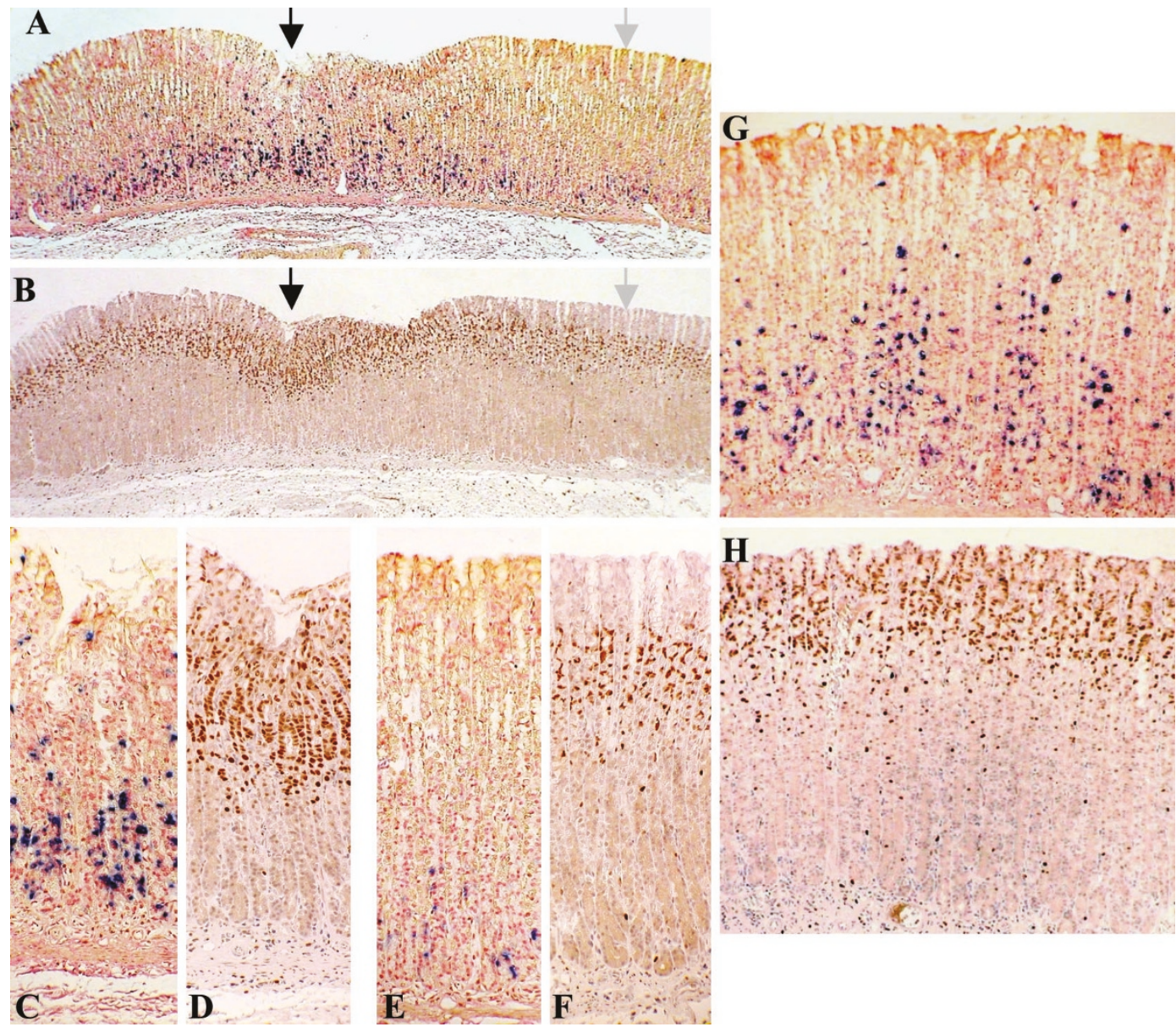

Figure 7.

Regl (in situ hybridization: $A, C$, and $E$ ) and proliferating cell nuclear antigen (PCNA) (immunohistochemistry: B, D, and F) performed on consecutive sections of rat stomach dosed with aspirin. Areas of epithelium that are injured (black arrow) show correlative increases in expression of both Regl and PCNA [A and B ( $\times X$ magnification), $C$ and $D(\times 20$ magnification) compared with adjacent, undamaged epithelium (gray arrows) $(A$ and $B(\times 5), E$ and $F(\times 20)]$. In adapted mucosa, areas of epithelium that are macroscopically normal but show strong expression of Regl $[G(\times 10 x)]$, also show increased expression of PCNA [H $(\times 10 x)]$ with positive staining apparent not only in cells in the neck region of the glands but also in surface epithelial cells-a pattern similar to that observed at sites of injury (D).

trefoil peptides are not induced by the comparatively small amount of daily damage caused by the doses of aspirin required for the induction of adaptation. Given the high basal expression levels of trefoils in normal, undamaged epithelium, it is feasible that a "threshold" of damage might be required before activation of further trefoil synthesis occurs and that trefoil expression in the intact mucosa surrounding superficial injury sites is sufficient to mediate mucosal healing requirements.

Gastric epithelial adaptation to NSAID-induced injury seems to be a complicated, multifactorial phenomenon characterized in part by increased expression of growth factors such as TGF- $\alpha$ and Regl, enhanced proliferation, and resistance to apoptosis. It is a process of general interest because it describes how epithelial surfaces respond and heal themselves after exposure to noxious stimuli and is also of practical importance when the damaging agents are widely used therapeutic drugs. The mechanisms that underlie adaptation have previously been poorly understood, but some of the pieces in the puzzle are now beginning to fit together.

\section{Materials and Methods}

\section{Animals}

The total RNA and protein samples used for the initial analysis of Regl and trefoil gene and protein expression were derived from stomach samples taken from animals dosed with vehicle or aspirin in a standard adaptation experiment as reported previously (Alderman et al, 2000). Briefly, hooded Wistar rats were divided into three groups of nine each: one group was given a daily dose of $0.5 \mathrm{ml}$ of vehicle $(1 \%$ methylcellulose) by gavage for 6 days (control); another group was given five daily doses of vehicle followed by a single dose of aspirin $120 \mathrm{mg} / \mathrm{kg}$ (single-dose); and the third group was given aspirin $120 \mathrm{mg} / \mathrm{kg}$ daily for 6 days (adapted).

Rats were killed under anesthesia 4 hours after the last dose of aspirin or vehicle. Mucosal damage was quantified by a blinded observer using digital planimetry on the color photographs from each stomach.

For the adaptation onset and offset experiment, 34 hooded Wistar rats were divided into six groups of 5 or 
6 and dosed according to the following 9-day schedule: the first group was given a daily dose of $0.5 \mathrm{ml}$ of $1 \%$ methylcellulose vehicle for 9 days (vehicle-only control); the second group was given a daily dose of vehicle for 8 days followed by a single dose of aspirin $(120 \mathrm{mg} / \mathrm{kg}$ ) on the ninth day (single dose); the third group was given a daily dose of vehicle for 6 days followed by a daily dose of aspirin for 3 days (adaptation onset); the fourth group was given a daily dose of vehicle for 3 days followed by a daily dose of aspirin for 6 days (adapted); the fifth group was given a daily dose of aspirin for the first 6 days and a daily dose of vehicle on Days 7 and 8, followed by a dose of aspirin on the ninth day (adaptation offset); and the sixth group was given a daily dose of aspirin for 6 days followed by a daily dose of vehicle for 3 days (adaptation offset control).

\section{RT-PCR}

Total RNA was extracted from stomach samples using a guanidinium thiocyanate-phenol method (Chomczynski and Sacchi, 1987). Total RNA (2 $\mu \mathrm{g})$ was reverse-transcribed into cDNA using $100 \mathrm{U}$ of Moloney murine leukemia virus reverse transcriptase (Promega, Madison, Wisconsin) primed with $0.2 \mu \mathrm{g}$ of oligo(dT) in $40 \mathrm{~mm}$ Tris- $\mathrm{HCl}$ (pH 8.3), $75 \mathrm{~mm} \mathrm{KCl,} 3 \mathrm{~mm}$ $\mathrm{MgCl}_{2}, 10 \mathrm{~mm}$ of dithiothreitol, and $1 \mathrm{~mm}$ dNTPs in a $20-\mu$ l volume at $37^{\circ} \mathrm{C}$.

Rat sense and antisense primers for the detection of mRNAs for the trefoil proteins (TFF1 and TFF2), Regl, and Regr, and the housekeeping gene ribosomal protein L32 (rL32) were designed based on GenBank sequences and were as follows: TFF1-sense 5'-TCT TCC CTG GAA GCT GCC AT, antisense 5'-CTT GCT GGT TCT CAA TGA CC; TFF2-sense 5'-GTC CAG TGG AGC AGA CAT, antisense 5'-CAC TGC TGA GGC TCA AGA; Regl-sense 5'-GAT CCC AAA AAT AAT CGC C, antisense 5'-GCA TCA CAA CTG TTA TCT CTC C; Regr-sense 5'-CTC AAG AAT GTC ATT AGC C, antisense 5'-GTA TCT CTC CCA CTA ACA CC; and rL32-sense 5'-AAC CCA GAG GCA TCG ACA ACA, antisense 5'-GAA CAC AAA ACA GGC ACA CA.

Optimization reactions were carefully performed to ensure that the intensities of the amplification products increased proportionally with increasing amounts of template. The optimum numbers of cycles for each primer pair were 16 for TFF1, 20 for TFF2, 26 for Regl, 28 for Regr, and 19 for rL32.

The amplification conditions were $10 \mathrm{~mm}$ Tris- $\mathrm{HCl}$, $50 \mathrm{~mm} \mathrm{KCl}, 2 \mathrm{~mm} \mathrm{MgCl}_{2}, 200 \mu \mathrm{m}$ dNTPs, 25 pmol each of sense and antisense primer, $1.25 \mathrm{U}$ of Taq polymerase (Promega), and $1 \mu$ l of RT reaction in a $20-\mu l$ volume. Parameters for each amplification cycle were as follows: denaturation at $95^{\circ} \mathrm{C}$ for 40 seconds, annealing at primer-specific temperature (TFF1, TFF2: $60^{\circ} \mathrm{C}$; Regl, Regr, rL32: $57^{\circ} \mathrm{C}$ ) for 40 seconds, and extension at $72^{\circ} \mathrm{C}$ for 1 minute.

PCR products were visualized by agarose/ethidium bromide electrophoresis. Gels were photographed and scanned, and the PCR products were quantified using the ImageMASTER software system (Pharmacia Biotech).

\section{Radioimmunoassay}

Protein extracts were prepared from rat stomach samples by homogenization in 10 volumes of ice-cold $1 \%$ NP-40 in 50 mm Tris (pH 8.8) buffer. Quantifications of TFF1 and TFF2 proteins by RIA were performed as previously described (Cook et al, 1997). The TFF1 and TFF2 primary antibodies were raised inhouse against synthetic decapeptides derived from the carboxyl terminal amino acid sequences of the rat TFF1 and TFF2 proteins, respectively.

\section{Western Blotting}

Protein extracts were prepared as outlined above, and $20-\mu \mathrm{g}$ aliquots were subjected to SDS-PAGE and electrophoretic transfer onto nitrocellulose membranes. Membranes were blocked with BSA before being incubated at $4^{\circ} \mathrm{C}$ overnight with Regl primary antibody (a kind gift from Dr. Brian Dieckgraefe, Washington University School of Medicine, St. Louis, Missouri). Membranes were rinsed and then incubated for 1 hour with peroxide-conjugated secondary antibody.

Immunoreactive proteins were visualized using the enhanced chemiluminescence system (Amersham). The films were scanned, and the intensities of the bands were measured using the ImageMASTER software system.

\section{Immunohistochemistry}

The patterns of expression of Regl and TFF1 proteins in control, aspirin-damaged, and aspirin-adapted stomach sections were visualized by immunohistochemistry. The antibodies used were the same as those used for the Western blotting and RIA as detailed above. For immunodetection of PCNA, a commercial mouse mAb was used (Dako).

Three full-thickness samples from each stomach were fixed in phosphate-buffered formalin $(10 \% \mathrm{v} / \mathrm{v}$ formalin, $0.40 \% \mathrm{w} / \mathrm{v}$ sodium dihydrogen orthophosphate monohydrate, $0.65 \% \mathrm{w} / \mathrm{v}$ disodium hydrogen orthophosphate anhydrous) for 16 hours, dehydrated in a series of alcohols, and embedded in paraffin and cut $(4 \mu \mathrm{m})$.

Sections were rinsed with Tris-buffered $0.15 \mathrm{~m} \mathrm{NaCl}$ (TBS), treated with 3\% hydrogen peroxide in methanol for 15 minutes, and preincubated with 5\% normal goat serum at room temperature for 30 minutes, followed by incubation with primary antibody diluted in TBS at $4^{\circ} \mathrm{C}$ overnight. After rinsing with TBS, sections were then incubated with biotinylated goat anti-rabbit IgG secondary antibody at room temperature for $30 \mathrm{~min}-$ utes, followed by avidin-horseradish peroxidase at room temperature for 30 minutes.

Positive labeling was developed by the addition of the peroxidase substrate solution, diaminobenzidine. Sections were counterstained with hematoxylin and photographed with a Nikon Coolpix 4500 digital camera. 


\section{Riboprobes for In Situ Hybridization}

Sense and antisense riboprobes were prepared via transcription of a pCRII Topo vector (Invitrogen) containing either a 600-bp cDNA encoding for rat Regl or a 233-bp cDNA encoding for mouse TFF1. Each plasmid was linearized with an appropriate restriction enzyme and was then transcribed into digoxigenin dUTP-labeled riboprobes using either SP6 or T7 RNA polymerase according to the method described by the manufacturer (Boehringer-Mannheim). The resulting probes were purified through a purification column (Qiagen), and the concentrations of each were estimated after separation by formaldehyde/3-(Nmorpholino) propanesulfonic acid (MOPS) agarose gel electrophoresis and comparison with a known standard.

\section{In Situ Hybridization}

The patterns of expression of the Regl and TFF1 genes in normal and aspirin-treated rat stomach sections were visualized by nonisotopic in situ hybridization using the digoxigenin-labeled riboprobes as detailed above. Stomach tissue was fixed overnight in $4 \%$ paraformaldehyde, paraffin embedded, and then cut into $4-\mu \mathrm{m}$ sections. Sections were dewaxed in xylene, hydrated though ethanol solutions to water, postfixed for 10 minutes (4\% paraformaldehyde), acetylated for 10 minutes $(0.1 \mathrm{~m}$ tiethanolamine/ $0.25 \%$ acetic anhydride), and permeabilized for 15 minutes $(15 \mu \mathrm{g} / \mathrm{ml}$ proteinase $\mathrm{K})$ with three 5 -minute washes in PBS between treatments. The sections were then dehydrated through a series of ethanol solutions and allowed to dry.

Hybridization of the sections was performed with a $200 \mathrm{ng} / \mathrm{ml}$ riboprobe in the hybridization solution $(50 \%$ formamide, $5 \times \mathrm{SSC}, 5 \times$ Denhardt $/ \mathrm{s}, 250 \mu \mathrm{g} / \mathrm{ml}$ yeast tRNA, $0.1 \%$ Tween, $500 \mu \mathrm{g} / \mathrm{ml}$ denatured herring sperm DNA) at $54^{\circ} \mathrm{C}$ overnight.

After hybridization, the sections were washed in high stringency conditions (down to $0.1 \times \mathrm{SSC} / 0.1 \%$ Tween at $54^{\circ} \mathrm{C}$ ) followed by incubation for 1 hour with sheep anti-digoxigenin primary antibody conjugated to alkaline phophatase (Boehringer-Mannheim) 1:1000 in $1 \%$ sheep serum $/ 0.1 \%$ Tween PBS. After extensive washing in PBS, the nitro blue tetrazolium/5-bromo4-chloro-3-indolyl-phosphate color reaction was allowed to proceed overnight, according to the Boehringer-Mannheim instructions. The color reaction was stopped by extensive washing in distilled water. The sections were counterstained using Nuclear Fast Red and Van Giesons reagent, mounted, and coverslipped. The sections were photographed through a Leica microscope using a Nikon Coolpix 4500 digital camera.

\section{Northern Blotting}

For Northern blot analysis, $20 \mu \mathrm{g}$ of total RNA was mixed with Glyoxal sample buffer (BioWhittaker Molecular Applications), subjected to electrophoresis through a MOPS- buffered agarose gel, and trans- ferred onto a Hybond-XL nylon membrane (Amersham). RNA was crosslinked onto the membrane by UV irradiation and specific mRNA detected by hybridization with a 32-P labeled cDNA probe. The Regl and rL32 probes used for the hybridizations were the products from the RT-PCR analysis described above. Hybridizations were performed in Rapid-hyb buffer (Amersham) according to the manufacturer's instructions. Washes were performed down to $1 \times \mathrm{SSC} / 0 / 1 \%$ SDS at $65^{\circ} \mathrm{C}$. Blots were exposed to film at $-80^{\circ} \mathrm{C}$ for 16.5 hours and 3.5 hours for Regl and rL32, respectively.

\section{Statistical Analysis of Data}

All data are expressed as means \pm SEM. Comparisons between groups were performed using the one-way ANOVA followed by the Student-Newman-Keuls test. A value of $p<0.05$ was considered statistically significant.

\section{References}

Alderman BM, Cook GA, Familari M, Yeomans ND, and Giraud AS (2000). Resistance to apoptosis is a mechanism of adaptation of rat stomach to aspirin. Am J Physiol Gastrointest Liver Physiol 278:G839-G846.

Alison MR, Chinery R, Poulsom R, Ashwood P, Longcroft JM, and Wright NA (1995). Experimental ulceration leads to sequential expression of spasmolytic polypeptide, intestinal trefoil factor, epidermal growth factor and transforming growth factor alpha mRNAs in rat stomach. J Pathol 175: 405-414.

Asahara M, Mushiake S, Shimada S, Fukui H, Kinoshita Y, Kawanami C, Watanabe T, Tanaka S, Ichikawa A, Uchiyama Y, Narushima Y, Takasawa S, Okamoto H, Tohyama M, and Chiba T (1996). Reg gene expression is increased in rat gastric enterochromaffin-like cells following water immersion stress. Gastroenterology 111:45-55.

Baumgartner A, Koelz HR, and Halter F (1986). Indomethacin and turnover of gastric mucosal cells in the rat. Am J Physiol 250:G830-G835.

Chinery R and Playford RJ (1995). Combined intestinal trefoil factor and epidermal growth factor is prophylactic against indomethacin-induced gastric damage in the rat. Clin Sci (Colch) 88:401-403.

Chomczynski P and Sacchi N (1987). Single-step method of RNA isolation by acid guanidinium thiocyanate-phenolchloroform extraction. Anal Biochem 162:156-159.

Cook GA, Yeomans ND, and Giraud AS (1997). Temporal expression of trefoil peptides in the TGF-alpha knockout mouse after gastric ulceration. Am J Physiol 272:G1540G1549.

Dignass A, Lynch-Devaney K, Kindon H, Thim L, and Podolsky DK (1994). Trefoil peptides promote epithelial migration through a transforming growth factor beta-independent pathway. J Clin Invest 94:376-383.

Doljanin K, Skeljo MV, Yeomans ND, and Giraud AS (1996). Adaptation of the gastric epithelium to injury is maintained in vitro and is associated with increased TGF-alpha expression. J Gastroenterol Hepatol 11:259-263. 
Dusetti NJ, Mallo GV, Ortiz EM, Keim V, Dagorn JC, and lovanna JL (1996). Induction of lithostathine/reg mRNA expression by serum from rats with acute pancreatitis and cytokines in pancreatic acinar AR-42J cells. Arch Biochem Biophys 330:129-132.

Dusetti NJ, Ortiz EM, Mallo GV, Dagorn JC, and lovanna JL (1995). Pancreatitis-associated protein I (PAP I), an acute phase protein induced by cytokines: Identification of two functional interleukin- 6 response elements in the rat PAP I promoter region. J Biol Chem 270:22417-22421.

Eastwood GL and Quimby GF (1982). Effect of chronic aspirin ingestion on epithelial proliferation in rat fundus, antrum, and duodenum. Gastroenterology 82:852-856.

Familari M, Cook GA, Taupin DR, Marryatt G, Yeomans ND, and Giraud AS (1998). Trefoil peptides are early markers of gastrointestinal maturation in the rat. Int J Dev Biol 42:783789.

Francis PJ, Southgate JL, Wilkin TJ, and Bone AJ (1992). Expression of an islet regenerating (reg) gene in isolated rat islets: Effects of nutrient and non-nutrient growth factors. Diabetologia 35:238-242.

Fukui H, Kinoshita Y, Maekawa T, Okada A, Waki S, Hassan S, Okamoto H, and Chiba T (1998). Regenerating gene protein may mediate gastric mucosal proliferation induced by hypergastrinemia in rats. Gastroenterology 115:1483-1493.

Graham DY, Smith JL, and Dobbs SM (1983). Gastric adaptation occurs with aspirin administration in man. Dig Dis Sci 28:1-6.

Graham DY, Smith JL, Spjut HJ, and Torres E (1988). Gastric adaptation: Studies in humans during continuous aspirin administration. Gastroenterology 95:327-333.

Gurr W, Yavari R, Wen L, Shaw M, Mora C, Christa L, and Sherwin RS (2002). A Reg family protein is overexpressed in islets from a patient with new-onset type 1 diabetes and acts as T-cell autoantigen in NOD mice. Diabetes 51:339-346.

Hanby AM, Poulsom R, Singh S, Elia G, Jeffery RE, and Wright NA (1993). Spasmolytic polypeptide is a major antral peptide: Distribution of the trefoil peptides human spasmolytic polypeptide and pS2 in the stomach. Gastroenterology 105:1110-1116.

Higham AD, Bishop LA, Dimaline R, Blackmore CG, Dobbins AC, Varro A, Thompson DG, and Dockray GJ (1999). Mutations of Reglalpha are associated with enterochromaffin-like cell tumor development in patients with hypergastrinemia. Gastroenterology 116:1310-1318.

Hurley JW and Crandall LA (1964). The effect of salicylates upon the stomachs of dogs. Gastroenterology 46:36-43.

Jeffrey GP, Oates PS, Wang TC, Babyatsky MW, and Brand SJ (1994). Spasmolytic polypeptide: A trefoil peptide secreted by rat gastric mucous cells. Gastroenterology 106: 336-345.

Jones MK, Tomikawa M, Mohajer B, and Tarnawski AS (1999). Gastrointestinal mucosal regeneration: Role of growth factors. Front Biosci 4:D303-D309.

Kawanami C, Fukui H, Kinoshita Y, Nakata H, Asahara M, Matsushima Y, Kishi K, and Chiba T (1997). Regenerating gene expression in normal gastric mucosa and indomethacin-induced mucosal lesions of the rat. J Gastroenterol 32:12-18.
Kazumori H, Ishihara S, Hoshino E, Kawashima K, Moriyama $\mathrm{N}$, Suetsugu $\mathrm{H}$, Sato $\mathrm{H}$, Adachi K, Fukuda R, Watanabe M, Takasawa S, Okamoto H, Fukui H, Chiba T, and Kinoshita $Y$ (2000). Neutrophil chemoattractant 2 beta regulates expression of the Reg gene in injured gastric mucosa in rats. Gastroenterology 119:1610-1622.

Kindon H, Pothoulakis C, Thim L, Lynch-Devaney K, and Podolsky DK (1995). Trefoil peptide protection of intestinal epithelial barrier function: Cooperative interaction with mucin glycoprotein. Gastroenterology 109:516-523.

Kobayashi S, Akiyama T, Nata K, Abe M, Tajima M, Shervani NJ, Unno M, Matsuno S, Sasaki H, Takasawa S, and Okamoto $H$ (2000). Identification of a receptor for reg (regenerating gene) protein, a pancreatic beta-cell regeneration factor. J Biol Chem 275:10723-10726.

Konturek JW, Dembinski A, Stoll R, Domschke W, and Konturek SJ (1994a). Mucosal adaptation to aspirin induced gastric damage in humans: Studies on blood flow, gastric mucosal growth, and neutrophil activation. Gut 35:11971204.

Konturek JW, Konturek SJ, Stachura J, and Domschke W (1998a). Helicobacter pylori-positive peptic ulcer patients do not adapt to aspirin. Aliment Pharmacol Ther 12:857-864.

Konturek PC, Brzozowski T, Konturek SJ, Elia G, Wright N, Sliwowski Z, Thim L, and Hahn EG (1997). Role of spasmolytic polypeptide in healing of stress-induced gastric lesions in rats. Regul Pept 68:71-79.

Konturek PC, Brzozowski T, Konturek SJ, Taut A, Sliwowski Z, Stachura J, and Hahn EG (1998b). Activation of genes for growth factors and cyclooxygenases in rat gastric mucosa during recovery from stress damage. Eur J Pharmacol 342: 55-65.

Konturek SJ, Brzozowski T, Stachura J, Dembinski A, and Majka J (1994b). Role of gastric blood flow, neutrophil infiltration, and mucosal cell proliferation in gastric adaptation to aspirin in the rat. Gut 35:1189-1196.

Lev R, Siegel HI, and Glass GB (1972). Effects of salicylates on the canine stomach: A morphological and histochemical study. Gastroenterology 62:970-980.

Levi S, Goodlad RA, Lee CY, Walport MJ, Wright NA, and Hodgson HJ (1992). Effects of nonsteroidal anti-inflammatory drugs and misoprostol on gastroduodenal epithelial proliferation in arthritis. Gastroenterology 102:1605-1611.

Lipscomb GR, Wallis N, Armstrong G, Goodman MJ, and Rees WD (1995). Gastric mucosal adaptation to etodolac and naproxen. Aliment Pharmacol Ther 9:379-385.

Mahr S, Neumayer N, Kolb HJ, Schepp W, Classen M, and Prinz C (1998). Growth factor effects on apoptosis of rat gastric enterochromaffin-like cells. Endocrinology 139:43804390.

Miyaura C, Chen L, Appel M, Alam T, Inman L, Hughes SD, Milburn JL, Unger RH, and Newgard CB (1991). Expression of reg/PSP, a pancreatic exocrine gene: Relationship to changes in islet beta-cell mass. Mol Endocrinol 5:226-234.

Playford RJ, Marchbank T, Chinery R, Evison R, Pignatelli M, Boulton RA, Thim L, and Hanby AM (1995). Human spasmoIytic polypeptide is a cytoprotective agent that stimulates cell migration. Gastroenterology 108:108-116.

Podolsky DK, Lynch-Devaney K, Stow JL, Oates P, Murgue B, DeBeaumont M, Sands BE, and Mahida YR (1993). Identification of human intestinal trefoil factor: Goblet cell-specific 
expression of a peptide targeted for apical secretion. J Biol Chem 268:6694-6702.

Rio MC, Bellocq JP, Daniel JY, Tomasetto C, Lathe R, Chenard MP, Batzenschlager A, and Chambon P (1988). Breast cancer-associated pS2 protein: Synthesis and secretion by normal stomach mucosa. Science 241:705-708.

Romano M, Lesch CA, Meise KS, Veljaca M, Sanchez B, Kraus ER, Boland CR, Guglietta A, and Coffey RJ (1996). Increased gastroduodenal concentrations of transforming growth factor alpha in adaptation to aspirin in monkeys and rats. Gastroenterology 110:1448-1455.

Shorrock CJ, Prescott RJ, and Rees WD (1990). The effects of indomethacin on gastroduodenal morphology and mucosal $\mathrm{pH}$ gradient in the healthy human stomach. Gastroenterology 99:334-339.

Shorrock CJ and Rees WD (1992). Mucosal adaptation to indomethacin induced gastric damage in man: Studies on morphology, blood flow, and prostaglandin E2 metabolism. Gut 33:164-169.

Skeljo MV, Cook GA, Elliott SL, Giraud AS, and Yeomans ND (1996). Gastric mucosal adaptation to diclofenac injury. Dig Dis Sci 41:32-39.

Skeljo MV, Giraud AS, and Yeomans ND (1992). Adaptation of rat gastric mucosa to repeated doses of non-salicylate non-steroidal anti-inflammatory drugs. J Gastroenterol Hepatol 7:586-590.

St John DJ, Yeomans ND, McDermott FT, and De Boer WG (1973). Adaptation of the gastric mucosa to repeated administration of aspirin in the rat. Am J Dig Dis 18:881-885.

Stachura J, Konturek JW, Dembinski A, and Domschke W (1994). Do infiltrating leukocytes contribute to the adaptation of human gastric mucosa to continued aspirin administration? Scand J Gastroenterol 29:966-972.

Stachura J, Konturek JW, Dembinski A, and Domschke W (1996). Growth markers in the human gastric mucosa during adaptation to continued aspirin administration. J Clin Gastroenterol 22:282-287.

Suemori S, Lynch-Devaney K, and Podolsky DK (1991). Identification and characterization of rat intestinal trefoil factor: Tissue- and cell-specific member of the trefoil protein family. Proc Natl Acad Sci USA 88:11017-11021.
Taupin D, Pedersen J, Familari M, Cook G, Yeomans N, and Giraud AS (2001). Augmented intestinal trefoil factor (TFF3) and loss of pS2 (TFF1) expression precedes metaplastic differentiation of gastric epithelium. Lab Invest 81:397-408.

Taupin DR, Pang KC, Green SP, and Giraud AS (1995). The trefoil peptides spasmolytic polypeptide and intestinal trefoil factor are major secretory products of the rat gut. Peptides 16:1001-1005.

Terazono K, Yamamoto H, Takasawa S, Shiga K, Yonemura $\mathrm{Y}$, Tochino $\mathrm{Y}$, and Okamoto $\mathrm{H}$ (1988). A novel gene activated in regenerating islets. J Biol Chem 263:2111-2114.

Tomasetto C, Masson R, Linares JL, Wendling C, Lefebvre O, Chenard MP, and Rio MC (2000). pS2/TFF1 interacts directly with the VWFC cysteine-rich domains of mucins. Gastroenterology 118:70-80.

Tomasetto C, Rio MC, Gautier C, Wolf C, Hareuveni M, Chambon P, and Lathe R (1990). hSP, the domain-duplicated homolog of pS2 protein, is co-expressed with pS2 in stomach but not in breast carcinoma. EMBO J 9:407-414.

Ulaganathan M, Familari M, Yeomans ND, Giraud AS, and Cook GA (2001). Spatio-temporal expression of trefoil peptide following severe gastric ulceration in the rat implicates it in late-stage repair processes. J Gastroenterol Hepatol 16: $506-512$

Wallace JL, McKnight GW, and Bell CJ (1995). Adaptation of rat gastric mucosa to aspirin requires mucosal contact. Am J Physiol 268:G134-G138.

Watanabe $\mathrm{T}$, Yonekura $\mathrm{H}$, Terazono $\mathrm{K}$, Yamamoto $\mathrm{H}$, and Okamoto H (1990). Complete nucleotide sequence of human reg gene and its expression in normal and tumoral tissues: The reg protein, pancreatic stone protein, and pancreatic thread protein are one and the same product of the gene. J Biol Chem 265:7432-7439.

Watanabe T, Yonemura $\mathrm{Y}$, Yonekura $\mathrm{H}$, Suzuki $\mathrm{Y}$, Miyashita $\mathrm{H}$, Sugiyama K, Moriizumi S, Unno M, Tanaka O, Kondo H, and et al (1994). Pancreatic beta-cell replication and amelioration of surgical diabetes by Reg protein. Proc Natl Acad Sci USA 91:3589-3592.

Yeomans ND, Saint John DJ, and de Boer WG (1973). Regeneration of gastric mucosa after aspirin-induced injury in the rat. Am J Dig Dis 18:773-780. 